\title{
A investigação criminal. Legitimidade e meios
}

\author{
The criminal investigation. Legitimacy and means
}

\author{
José ANTONIO PAgANeLla BOSCHI ${ }^{1}$
}

Advogado criminalista

\begin{abstract}
RESUMO: O artigo analisa a fase pré-processual da persecução penal e identifica o inquérito policial como instrumeto por excelência para a investigação. Destaca que a atribuição para investigar não é exclusiva da Polícia Judiciária e aponta outras autoridades administrativas às quais a lei confere poder de investigar por meio de expedientes não policiais, igualmente aptos a propiciar a formação da justa causa, necessária à abertura da fase judicial da persecução penal.

Palavras-chave: Investigação policial. Autoridades com atribuições para investigar. Inquérito Policial, termo circunstanciado e Expedientes não policiais.
\end{abstract}

\begin{abstract}
The article analyzes the pretrial stage of criminal prosecution and the police investigation identifies as instrumeto par excellence for research. Highlights that the assignment is not solely to investigate the judiciary police and other administrative authorities points to which the law confers power to investigate by means of strategies than the police also able to facilitate the formation of good cause, the court required the opening phase of prosecution.

Keywords: Police investigation. Authorities with powers to investigate. Police Investigation, detailed Expedients term and non-police.
\end{abstract}

\section{INTRODUÇÃO}

A persecução penal é exercitada em duas fases bem distintas: a administrativa e a judicial, consistindo a primeira fase preparatória para o desencadeamento, na fase judicial, da ação e do processo de conhecimento.

A fase administrativa está a cargo, em regra, das policiais militares e civis, estaduais ou federais, respectivamente, com atuação preventiva e repressiva. Em paralelo, atuam as polícias municipais, com atribuições restritas ao controle do sistema viário e à proteção dos prédios e locais públicos.

Nessa fase, a atuação preventiva (a cargo das polícias militares) é destinada a assegurar a preservação da ordem pública, ao passo que a atuação repressiva (a cargo da polícia civil ou "judiciária) é repressiva e ocorre, em regra, após o cometimento do ilícito. A polícia "judiciária" colhe provas para formar justa causa indispensável à ação penal (art. 395, III, CPP), seja por meio de inquérito, de termo circunstanciado ou de meras peças de informação.

Revestindo-se as provas de idoneidade, sob todos os aspectos, sobre a existência e a autoria do fato, a autoridade promoverá o indiciamento. As provas, para o indiciamento, não precisam ser cabais, definitivas, eis que, nessa fase, o princípio que a domina é o do in dubio pro societate.
$\mathrm{O}$ indiciamento, portanto, não pode ser, como bem alerta Alexandre Salim, um ato arbitrário, já que na dependência desses “... fortes indícios que agarantam a ligação do sujeito á conduta penal. A mera suspeita ou a simples opinião desfavorável a respeito de alguém não pode, por si só, levar ao indiciamento, sob pena de caracterização de constrangimento ilegal"'2.

Conquanto seja historicamente exercida pela polícia judiciária, a investigação preparatória da ação e do processo criminal não é exclusiva da autoridade policial, pois a norma do par. único do art. 4º do CPP, declara que a "competência" (rectius: a atribuição) da polícia judiciária "não excluirá a de autoridade administrativa, a quem por lei seja cometida a mesma função". Desse modo, ao lado do inquérito há outros instrumentos de idêntica natureza administrativa e aptidão que podem também demonstrar a presença de justa causa e assim capacitar o acusador a oferecer denúncia ou queixa, conforme será destacado, com preocupação didática, neste breve ensaio.

\section{O INQUÉRITO POLICIAL}

O inquérito é o instrumento por excelência utilizado pela polícia judiciária em suas atividades investigatórias. Sua natureza é administrativa e, por isso, os eventuais defeitos não afetam a validade do 
processo judicial. Essas atividades são inquisitivas (como sugere, aliás, a expressão inquérito), de modo que, nessa fase administrativa, não há direito de defesa ou contraditório. Diz-se que autor do fato é objeto da investigação, conquanto essa assertiva possa comportar sérios questionamentos, pois, a rigor, não há plena interdição de direitos, pois tem direito a receber cópias do inquérito (Súmula Vinculante n⿳⼈ㅡㄹ 14 ), a não falar à autoridade, a não produzir provas contra si, etc.

Em nosso meio a investigação criminal foi regulamentada pela Lei $\mathrm{n}^{\mathrm{o}} 261$, de 1.871, mas a palavra "inquérito fó apareceu em nosso direito no texto regulamentador do Decreto no 4.824 de 22 de novembro do mesmo ano.

Consoante o referido decreto, o inquérito seria "escrito" e constitituído por “... todas as diligências necessárias para o descobrimento dos fatos criminosos, de suas circunstâncias e dos seus autores e cúmplices".

Embora incorporado à tradição brasileira, o inquérito vem sendo alvo de críticas e mais críticas. Registra muito bem Alexandre Salim, que a morosidade da tramitação "prejudica a prestação jurisdicional: é oneroso, já que muitas das provas que ali se realizam devem ser repetidas em juízo: não há defesa efetiva do investigado, em descompasso com a realidade constutucional vigente, de um sistema de direitos e garantias: comentam-se abusos ocorridos no interior dos mais diversos órgãos policiais, tais como corrupção e tortura: não é instrumento hábil para a apuração de infrações cometidas por administradores públicos, já que a autoridade policial, subordinada que é ao Poder Executivo, nã oteria a independência necesária para a sua atividade e nem estaria livre de eventuais pressões políticas"3, aspecto que, segundo o mesmo autor, tem acentuado a tendência de entregar ao MP a direção da investigação.

Endossamos, por isso, a crítica de René Ariel Dotti ${ }^{4}$ quanto à necessidade de dotar-se a Polícia Judiciária de orçamento próprio, condizente infraestrutura técnica e ainda melhores quadros, mediante pagamento de salários condignos, fornecimento de veículos e equipamentos modernos, etc., para que menos com armamentos e mais com inteligência e estratégia, melhoremos nossa posição no ranking na luta contra a violência e o crime. Acrescentamos: a polícia, para sua maior independência, deve ter autonomia administrativa, incumbendo aos seus membros a eleição da Chefia, como ocorre no Ministério Público.

$O$ inquérito nasce com a investigação e se desenvolve com ela e todas as providências precisam ser registradas, documentadas, formalizadas, instan- taneamente nos "autos", para que, ao seu exame, possa-se reconstruir todos os passos percorridos. De fato, uma coisa é o inquérito e outra são os autos correspondentes. A qualidade do inquérito é aferida mediante singela leitura dos autos...

É no lugar da infração que a autoridade deve instaurar o inquérito, isto é, a investigação, algo semelhante ao que se verifica no tocante ao processo judicial (art. 70 do $\mathrm{CPP}$ ). O desrespeito à regra, contudo, não enseja a nulidade do inquérito ou mesmo do processo por causa da natureza administrativa da investigação.

O inquérito policial deve ser instaurado de ofício pela polícia judiciária (em delitos de ação pública incondicionada), por requisição do MP ou do Juiz e ainda mediante representação e requerimento do Ofendido, nos delitos de ação pública condicionada à representação ou de ação de iniciativa privada, respectivamente (art. $5^{\circ}$ e incisos, do CPP). A atuação de ofício é consentânea com o princípio da obrigatoridade da ação penal pública, pois não teria sentido o dever do MP de oferecer a denúncia desacompanhado do dever da autoridade da polícia judiciária de abrir a investigação por crimes da mesma natureza.

Anote-se, entretanto, que se o suspeito ou autor do fato for parlamenar federal, o STF, pacificamente, entende que por causa da prerrogativa de foro assegurada pela $\mathrm{CF}$ aos membros do Congresso, a abertura ou prosseguimento de investigações formais, independentemente da natureza do delito ou da ação penal correspondente, dependerão de prévia licença da Corte.

A prerrogativa de foro não é privilégio pessoal, pois se insere na necessidade de preservar-se a hierarquia entre cargos e funções e de resguardar e proteger os titulares desses cargos e funções de pressões indevidas.

Logo, a autoridade policial estará impedida de abrir e de dar sequência à investigação de fato que chegar ao seu cocnhecimento, envolvendo parlamentar federal, nada obstante a regra do inciso I do art. $5^{\circ}$ do CPP, dele dando imediata ciência ao MP para que a licença ao STF possa ser requerida pelo Procurador-Geral da República.

Consoante paradigática decisão relatada pelo ministro Sepúlveda Pertence,

Se a Constituição estabelece que os agentes políticos respondem, por crime comum, perante o STF (CF, art. 102, I, b), não há razão constitucional plausível para que as atividades diretamente relacionadas à supervisão judicial (abertura de procedimento investigatório) sejam retiradas do controle judicial do STF. A iniciativa do procedimento investigatório deve ser confiada ao MPF contando com a supervisão 
do Ministro-Relator do STF. 10. A Polícia Federal não está autorizada a abrir de ofício inquérito policial para apurar a conduta de parlamentares federais ou do próprio Presidente da República (no caso do STF). No exercício de competência penal originária do STF (CF, art. 102, I, 'b’ c/c Lei no 8.038/1990, art. $2^{\circ}$ e RI/STF, arts. 230 a 234), a atividade de supervisão judicial deve ser constitucionalmente desempenhada durante toda a tramitação das investigações desde a abertura dos procedimentos investigatórios até o eventual oferecimento, ou não, de denúncia pelo dominus litis $^{5}$.

Registre-se que a prerrogativa dos parlamentares federais de só serem investigados mediante licença prévia do Supremo Tribunal Federal não se estende aos integrantes dos Legislativos estaduais e municipais. Por conseguinte, os deputados estaduais e os vereadores podem ser investigados livremente pela autoridade policial e serem denunciados perante o Tribunal de Justiça ou o juiz da comarca, respectivamente, mas, bem apreendido o sentido, a extensão e a profundade do do princípio da simetria, que rege o modelo federativo, também em relação a eles a investigação só poderia ser aberta ou prosseguir mediante prévia licença do Tribunal de Justiça ou do Juiz da comarca, requerida pelo Procurador-Geral de Justiça ou pelo Promotor da comarca, respectivamente.

Em todos os casos regidos pela prerrogativa de foro, as pessoas destituídas da prerrogativa de foro, suspeitas de prática do fato como co-autores ou participantes serão com eles próprios investigadas e acusadas, embora a possibilidade, sempre excepcional, de cisão da investigacão e do próprio processo (art. 80 do CPP), quando razões relevantes se fizerem sentir, como a complexidade do caso, a dificuldade no recolhimento da prova, ou forem muitos os investigados ou denunciados. O caso mensalão é paradigmático - não obstante votos no próprio STF favoráveis ao desmembramento, nesse e noutros casos.

A prerrogativa de foro vem sendo questionada pela população, estiumulada pela mídia, sob o argumento de que protege políticos corruptos, uma vez que os Tribunais de Apelação, o Superior Tribunal de Justiça ou o próprio Supremo Tribunal Federal estão sobrecarregados de trabalho e por isso não conseguem instruir os processos e proferir as sentenças em tempo hábil, ensejando prescrições. O tema é controverso e, pela extensão e profundidade, não o dissecaremos neste momento.

Além dos Parlamentares Federais, há outras autoridades (prefeitos municipais, promotores, magistrados, governadores, secretários de estado, etc), presidente da república, ministros, procuradadores-Gerais, etc., que também tem o direito de serem processadas e julgadas por órgãos colegiados do Tribunal de Justiça, do STJ ou do próprio STF pelas infrações cometidas.

Essas exceções serão analisadas em itens específicos, logo abaixo, por razões meramente didáticas.

\section{O TERMO CIRCUNSTANCIADO (LEI 9.099/90)}

Em 1988 instalou-se em nosso País uma nova economia jurídico-penal pois a Constituição Federal criou no inciso I de seu artigo 98 os Juizados Especiais Criminais com competência para julgar infrações de menor potencial ofensivo, entendidas hoje, como tais, aquelas cujas penas máximas cominadas não ultrapassam a dois anos ${ }^{6}$.

As provas de justa causa, no JEC, serão apuradas em expediente denominado de "termo circunstanciado". Este é maios simplificado, constituido, basicamente, pela prova pericial, se for o caso, registro de ocorrência e, eventualmente, depoimentos do autor do fato e da vítima. É claro que, também na esfera do JEC, há que atentar-se para as regras que dispõem sobre a prerrogativa de foro.

Eventualmente, certas infrações definidas como de menor potencial ofensivo poderão revestir-se de peculiaridades tais que a apuração da verdade deve ser realizada em procedimento mais amplo e formal $\left(\S 2^{\mathrm{O}}\right.$ do art. 77 da Lei 9.099/95), de que são exemplo as previstas na Lei da Propriedade Industrial (no 9.279/96) que exigem, via de regra, produção de complexa prova pericial. Não sendo encontrado o autor do fato para ser citado, outrossim, os autos serão encaminhados ao juízo comum para que a ação tenha início segundo o procedimento comum específico (par. único do art. 66).

A instauração do termo circunstanciado é da atribuição da polícia civil, havendo controvérsia sobre a possibilidade de também ser instaurado também pelas polícias militares.

Amparado na doutrina de Nereu Giacomolli ${ }^{7}$, Turma Recursal do Juizado Especial de Porto Alegre ${ }^{8}$ respondeu afirmativamente à questão proposta, sob o fundamento de que nas infrações afetas à Justiça Consensual não há propriamente uma investigação policial, uma apuração pormenorizada, um inquérito policial, ou seja, atividade típica da polícia judiciária. Basta a lavratura de um termo circunstanciado, isto é, a materialização do fato e de suas circunstâncias, com a identificação dos envolvidos e das possíveis testemunhas, consignando-se uma sintética conclusão do que foi informado.

Convocado a emitir seu entendimento sobre o tema, o Superior Tribunal de Justiça, reconheceu 
que “... a providência prevista no art. 69, da Lei n⿳ 9099/95, é da competência da autoridade policial sem consubstanciar ilegalidade a circunstância de utilizar o Estado o contingente da Polícia Militar, em face da deficiência dos quadros da Polícia Civil"9.

O STF, todavia, declarou que o " $\$ 5^{\circ}$ do art. 144 da Carta da República atribui às polícias militares a tarefa de realizar o policiamento ostensivo e a preservação da ordem pública”, não podendo-se confundi-la “... com as funções de polícia judiciária e apuração de infrações penais, estas, sim, de competência das polícias civis" 10 .

De fato, a divisão do trabalho e os controles administrativos justificam o cuidado com o risco de superposição de atribuições ou competências para alcançar-se efetividade na execução do orçamento plúblico.

\section{INVESTIGAÇÕES AUTORIDADES NÃO POLICIAIS. OS EXPEDIENTES NÃO POLICIAIS}

Como dissemos antes, embora seja da Polícia Federal e das Polícias Civís, conforme a matéria, a atribuição para instaurar e presidir o inquérito policial (inc. IV e $\S 4^{\circ}$ do art. 144 da CF) há outras exceções que precisam ser também apontadas e comentadas neste momento.

São elas:

\section{(i) As CPIs}

As Comissões Parlamentares de Inquérito (CPIs) surgiram na fase Imperial e, conforme José Celso de Mello Filho, no contexto da função parlamentar de controle e fiscalização do Executivo ${ }^{11}$, conquanto tenham sido formalmente reconhecidas só na Constituição de 1934.

Nos atuais termos do art. 58, $\S 3^{\circ}$ da CF, por meio de CPIs, as Casas Legislativas Federais (Câmara e Senado) detém poderes para investigar fatos certos, suscetíveis de imposição de responsabilidades funcionais, administrativas e também penais.

A CPI é convocada e instalada para apurar, em prazo préfixado, fato certo e bem determinado e não qualquer fato ${ }^{12}$ pelo tempo que bem entender.

Consideram-se como fatos certos aqueles que, para Pontes de Miranda, "digam com a vida constitucional do país, para que dele tenha conhecimentoa preciso e suficiente, a Câmara dos Deputados ou o Senado Federal", que se "encadeiem ou se seriem"13. A exigência guarda paralelo com os requisito formal constante do artigo 41 do CPP de modo que nos moldes da denúncia ou queixa o ato de instalação de CPI deve indicar o fato com todas as suas circunstâncias inclusive para que as pessoas convocadas a depor como suspeitas ou investigadas, possam conhecer a extensão, a longitude e a profundidade da investigação e também proteger-se contra a autoincriminação (nemo se detegere).

Não obstante, o Supremo Tribunal Federal reconheceu, oportunamente, “... que fatos conexos aos inicialmente apurados podem, também eles, passar a constituir alvo de investigação da Comissão Parlamentar em causa. Contudo, para que isso aconteça, torna-se necessária a aprovação de aditamento"14. A decisão vai muito bem ao encontro dos objetivos de celeridade e de economia por evitar o inconveniente da instauração de outra CPI, em prejuízo do exercício da atividade legiferante em benefício da economia interna em serviços, diligências, reuniões, envolvimento de funcionários, etc.

As limitações relacionadas ao prazo e a certeza do fato visam a evitar que a CPI seja transformada em instrumento para perseguições políticas, devassas infundadas, em detrimento do bom andamento dos serviços públicos e da idoneidade dos titulares dos cargos ou funções públicas.

Inexiste previsão na Lei Maior sobre atribuições similares das Assembleias Legislativas e das Câmaras de Vereadores, mas,como ensinam, aliás, Andrei Schmidt e Luciano Feldens ${ }^{15}$, dando por fundamento o princípio da simetria, são pacificamente reconhecidas pela doutrina e pela jurisprudência.

Justificável a conclusão: “... a função primordial do Poder Legislativo é a de legislar" - como bem destaca Gulherme Rodrigues Abrão, em trabalho sobre as CPIs ${ }^{16}$ - “... mas, além daquela função, há outra, que é a de fiscalizar, controlar e investigar os atos emanados do Poder executivo, sem que isso represente violação ao princípio da separação dos poderes" ${ }^{17}$.

O grande Aliomar Baleeiro, constituinte que seria festejado também como ministro do Supremo Tribunal Federal, na boa lembrança de Odacir Klein, havia apresentado uma Emenda (no 955) visando suprimir do texto enviado à aprovação disposições que autorizavam o Legislativo a criar CPIs. Segundo as suas palavras

É inteiramente supérflua a disposição porque, no desempenho de suas funções, ambas as Câmaras podem recorrer aos inquéritos sobre quaisquer fatos, determinados ou não assim como a todo e qualquer meio idôneo, que não lhe seja vedado por cláusula expressa, ou implícita, da Constituição... Tais Comissões de inquérito sempre e sempre foram criadas pela Câmaras inglesas e norteamericanas com poderes tão grandes, que podem trazer compulsoriamente à sua presença, prender 
e fazer punir 'por desacato' perante a Corte de Justiça de Colúmbia, os indivíduos recalcitrantes. Nenhum dispositivo constitucional, ou da Emenda à Constituição, entretanto, julgou-se necessário para esse fim ${ }^{18}$.

Segundo as Leis 1.579/52 (art. $2^{\circ}$ ) e 4.595/64 (art. 38), as Comissões Parlamentares detém atribuições para ordenar diligências, convocar ministros e deputados, tomar depoimentos de autoridades, ouvir suspeitos, indiciá-los, se for o caso, intimar testemunhas e colher os seus depoimentos, requisitar ou ordenar a busca de documentos, requisitar serviços de terceiros e locomover-se para onde for necessário e com vistas à implementação da finalidade da convocação.

O investigado tem o dever de atender as convocações da CPI e se não comparecer no dia e hora marcado para ser ouvido poderá ser conduzido coercitivamente, por ordem do Presidente, titular de poderes equivalentes ao das autoridades judiciais $\left(\mathrm{CF} \text {, art. 58, } \S 3^{\mathrm{o}}\right)^{19}$, embora não seja titular de jurisdição.

Embora as CPI's atuem inquisitorialmente, temse reconhecido aos suspeitos ou investigados o direito de permanecerem calado e de serem acompanhados por advogados, ao estilo das investigações realizadas pela autoridade policial ou outras agências estatais autorizadas em lei. Inúmeros habeas corpus foram concedidos pelo STF para assegurar esses direitos.

As testemunhas também tem o dever de comparecer às audiências e se faltarem ao ato sem justificativa séria poderão ser conduzidas por ordem do Presidente da $\mathrm{CPI}^{20}$, eis que presente o interesse público na apuração dos fatos.

Como acentuou José Celso de Mello Filho, citando precedente do Tribunal de Justiça do RGS, "no direito de investigar está ínsito o poder coercitivo de obter as informações necessárias ao esclarecimento da investigação, não sendo lícito, pois, à testemunha, recusar depor perante as comissões parlamentares de inquérito constituídas pelas Assembleias Legislativas" 21 .

As CPIs estão legitimadas, ainda, a requisitar informações junto às instituições financeiras e, também a decretar a quebra do sigilo fiscal, bancário e telefônico dos investigados ${ }^{22}$. Por quebra do sigilo telefônico devemos entender a possibilidade de requisição perante as concessionárias dos registros existentes sobre os telefonemas realizados e recebidos pelo suspeito, ficando, como é óbvio, a CPI, responsável pela indevida publicação das informações recebidas.

Esse poder de requisição não abrange o acesso às conversas ao telefone realizadas pelo suspeito com outras pessoas (interceptação telefônica), haja vista a reserva de jurisdição insculpida no inciso XI do artigo $5^{\text {o }}$ da CF. segundo a qual apenas o Poder Judiciário, fundamentadamente, está autorizado a autorizar a quebra do sigilo de correspondência, das comunicações telegráficas, de dados e telefônicas e isso nas hipóteses e na forma que a legislação específica estabelecer e para os fins da investigação ou da instrução processual penal $^{23}$.

A CPI não detém poderes para decretar a prisão preventiva, haja vista os termos do inciso LXI do artigo $5^{\circ}$ da Constituição Federal, de modo que uma providência nesse sentido dependerá de representação da CPI ao Poder judiciário e de decisão fundamentada do magistrado competente com invocação de motivo concreto e real dentre os cabíveis nas figuras do artigo 312 do Código de Processo Penal.

É claro que a prisão em flagrante é perfeitamente admitida na órbita das Comissões Parlamentares de Inquérito ou fora delas (Súmula 397 do STF) conquanto sujeitas à homologação judicial - eis que suscetível de ser imposta por qualquer pessoa do povo (art. 5으, inc. LXI e art. 301 e seguintes do CPP).

Observe-se, entretanto, que se o autor do fato for parlamentar, a prisão em flagrante só será possível se o crime for inafiançável, devendo os autos respectivos serem remetidos em 24 horas à respectiva Casa (Câmara ou Senado) para a deliberação pelo voto da maioria de seus membros sobre a sua manutenção ou revogação da prisão (art. 53, § 2을 da CF e Regimentos Internos da Câmara e do Senado).

Em voto no STF, o Ministro Victor Nunes ensinava que "Não podia, realmente, o poder de polícia das Casas do Congresso deixar de ficar adstrito ao exercício, propriamente, da função parlamentar. Esta é uma prerrogativa que resguarda o Poder Legislativo de qualquer atentado, em nome de sua independência garantida pela Constituição Federal"24.

Por último: esgotados os trabalhos da CPI, os autos, com a manifestação do Plenário sobre o Relatório apresentado, deverão ser enviados ao Ministério Público, para os fins de direito.

\section{(ii) Investigação pelo Poder Judiciário}

Já anotamos e, por razões didáticas, voltamos a anotar que é do Poder Judiciário e não da Polícia a atribuição para investigar magistrado federal ou estadual.

O artigo 33 da Lei Complementar no 35, de 14 de março de 1979 dispõe, in verbis:

Quando, no curso de investigação, houver indício da prática de crime por parte do magistrado, a autoridade policial, civil ou militar, remeterá os 
respectivos autos ao Tribunal ou órgão especial competente para o julgamento, a fim de que prossiga na investigação.

Então, toda vez que as autoridades policiais ou não policiais apurarem a existência, em tese, de ilícito penal cometidos por magistrados, deverão interromper as atividades investigatórias e repassar as informações e os elementos de prova recolhidos para o Tribunal competente continuar as invetigações e se for o caso ensejar posteriormente a instauração do processo criminal, nos termos da Lei 8.038/90.

O expediente será distribuido na Corte a um Relator que conduzirá as investigações e após a sua conclusão remeterá os autos à apreciação do Chefe do Ministério Público (federal ou estadual). Se o chefe do MP necessitar esclarecer ponto relevante, essa autoridade poderá requisitar diligências, inclusive diretamente (art. 16 do CPP e art. $1^{\circ}$, $\S 1^{\circ}$ o da Lei $n^{\circ}$ 8038/90).

Se não for caso não é de denúncia, o ProcuradorGeral tem a alternativa de requerer ao Tribunal competente o arquivamento da investigação - com o envio dos autos do inquérito ou peças de informação ao arquivo judiciário. $\mathrm{O}$ Tribunal não pode recusar $\mathrm{o}$ requerimento, por não aplicar-se ao Procurador-Geral (nos Estados e na União) a disciplina jurídica do artigo 28 do CPP. O princípio da independência funcional entre o MP e o Poder Judiciário, aliás, é constitucional (art. 129).

Entendemos possível, por tais razões, que o arquivamento da investigação possa ocorrer na própria Procuradoria-Geral, embora o recomendável, para assegurar-se maior transparência, seja a formulação de pedido nesse sentido ao Poder Judiciário.

\section{(iii) Investigação pelo pelo Ministério Público}

Outra exceção à regra do inciso I do art. 5을 do CPP, que impõe dever de instauração de ofício, pela Polícia, de inquérito por crime de açao pública, está prevista no artigo art. 18, inc. II, letra "f", da Lei Complementar $\mathrm{n}$ - 75/93. Nos mesmos moldes das prerrogativas asseguradas aos magistrados, os membros do MP só poderão ser invetigados pelo próprio Ministério Público.

Essa disposição normativa foi reafirmada em 1993 pela Lei 8.625 (inciso II e parágrafo único do art. 41 da Lei Federal no 8625, de 12.2.93) conhecida como a Lei Orgânica Nacional do Ministério Público.

Assim, em caso de suspeição ou comprovada autoria de delito imputável a membro do MP, “ ... a autoridade policial, civil ou militar remeterá, imediatamente, sob pena de responsabilidade, os respectivos autos ao Procurador-Geral de Justiça, a quem competirá dar prosseguimento à apuração" (parágrafo único do art. 41 e art. $59, \S 2$ o do Estatuto do MP do RS - Lei $6536 / 73)^{25}$.

Fora da hipótese acima ventilada, o Ministério Público, ao que nos parece, não poderá substituir a Polícia Judiciária no campo investigatório, embora necessário reconhecer que o tema é bastante polêmico na doutrina e nos Tribunais ${ }^{26}$.

Luciano Feldens e Andrei Zenkner Schimidt ${ }^{27}$, por exemplo, amparados nos inciso VI ou VIII ou IX do art. 129 da CF, no artigo 8을 inciso I da Lei Complementar no 75/93 e no art. 26, inc. I da Lei no 8625/93, sustentam que esses dispositivos autorizam ao a fazer o mais, isto é, a requisitar inquéritos e, por isso, concluem carecer de sentido proibi-lo de fazer o menos.

Essa posição já foi sufragada pelo Superior Tribunal de Justiça por meio de suas $5^{\mathfrak{a}}$ e $6^{-}$Turmas Criminais ${ }^{28}$ e negada pelo $\mathrm{STF}^{29}$, em cuja Corte pende, aliás, o julgamento da ADIN no 3806 proposta pela Associação Nacional dos Delegados de Polícia contra a Resolução no 13 do Conselho Nacional do MP, que, comportandose como se a matéria fosse pacífica, editou a citada Resolução com a intenção de "oficializar" a atividade investigatória pelos promotores ${ }^{30}$.

Em estudo crítico, Cezar Roberto Bitencourt ${ }^{31}$ asseverou que essa Resolução padece do vício da inconstitucionalidade, por revelar-se não como um instrumento de regulação e sim como mero pretexto para criação de poderes investigatórios pela via indevida e ao arrepio da Constituição.

Seria possível afirmar outrossim que por deter atribuições constitucionais para requisitar a abertura de inquérito criminal e para instaurar, internamente, inquéritos civis públicos (inc. III do art. 129 da CF) ${ }^{32}$ e mesmo oferecer denúncia com base em quaisquer outros elementos de prova $^{33}$, o poder do Ministério Público de investigar estaria ínsito, isto é, "faria parte", desse conjunto de atribuições, como propõe a teoria dos poderes implícitos? ${ }^{34}$

Sem necessidade de discutirmos a amplitude do artigo $144 \mathrm{da} \mathrm{CF}$, nem de dissecarmos essa teoria, posto que bem conhecida, parece-nos, data venia, que, acaso tivesse sido intenção do legislador constituinte conferir ao MP essa atribuição por certo a teria exteriorizado, quando podia, em inciso próprio do art. 129 da mesma Lei Maior.

Não se diga ainda que as atribuições investigatórias conferidas pela lei aos três Poderes, às CPIS, à Receita Federal, ao COAF ou ao Banco Central atestariam que a mesma atividade poderia ser também exercida pelo Ministério Público por ser uma instituição voltada, em essência e finalidade, à defesa do interesse público. 
É que, conforme explicou Bitencourt, amparado em José Afonso da Silva ${ }^{35}$ e em Ada Pellegrini Grinover ${ }^{36}$, todos os casos citados entram na órbita das exceções autorizadas pelo parágrafo único do artigo $4^{\mathrm{O}}$ do CPP, "o que não se verifica no caso de poderes investigatórios criminais atribuídos ao Ministério Público.

De qualquer sorte, se vier a prevalecer entendimento oposto ao que ora estamos expondo, parece-nos que a atividade investigatória pelo MP deverá ser amplamente regulamentada, em resguardo às garantias constitucionais, dentre elas, a de acesso à investigação.

É do nosso conhecimento que essa garantia foi equivocada e paradoxalmente negada pelo próprio MP em investigação por ele próprio conduzida e também por instâncias do Poder Judiciário, todos provavelmente pressionados pelos elevados índices de violência e de criminalidade, não obstante a Súmula Vinculante $\mathrm{n} \mathrm{o}$ 14, o Estatuto da OAB, as garantias constitucionais e os reiterados e confortadores arestos dos Tribunais Superiores.

Convém lembrar, outrossim, que a rejeição da PEC no 37 não alterou o quadro aqui desenhado, porque o que essa PEC visava era, nada mais, nada menos, assegurar, expressamente, na Lei Maior, o monopólio da Polícia para investigar, monopólio que atualmente ela não detém, haja vista o disposto no parágrafo único do art. 4 do CPP e, na sua esteira, o disposto nas leis esparsas, acima comentadas. Noutras palavras: com a rejeição da $\mathrm{PEC}$ no 37 a questão continua em aberto até que o coledo STF aprecie as ADINS pendentes.

\section{(iv) Investigação para apuração de falta funcional no serviço público, constitutiva de infração criminal}

É comum na Administração Pública, por força de regras estatutárias, a instauração de inquéritos administrativos (denominados também de sindicâncias) ou processos administrativos destinados a recolher informações sobre a prática de falta funcional ou a impor o sancionamento previsto em direito administrativo, respectivamente.

Não obstante a natureza inquisitorial das sindicâncias e dos inquéritos ${ }^{37}$, vem-se entendendo que o servidor público sob investigação tem direito à ampla defesa e ao contraditório, haja vista o regramento constitucional (art. 5으, inc. LV), prevenindo-se arguição de nulidade do futuro processo administrativo ${ }^{38}$.

Ademais, os inquéritos, que, no dizer de Gasparini, são "disciplinares" por serem grandemente utilizados pela administração pública para a "apuração de falta e punição dos agentes públicos, na sua necessária utilização para demissão de servidor estável e nas peculiaridades que encerra", que nada tem de inquisitório, de modo que "a semelhança que se quer estabelecer (entre o processo administrativo disciplinar) com o inquérito policial, cuja essência é inquisitorial, é improcedente"39 (inserção entre parêntesis não constante do original).

A Lei no 8.112/90, que "Dispõe sobre o Regime Jurídico dos Servidores Públicos Civis da União, das Autarquias e das Fundações Públicas Federais", declara, no art. 149, que "O processo disciplinar será conduzido por comissão composta de três servidores estáveis designados pela autoridade competente, observado o disposto no $\S 3^{\circ}$ do art. 143, que indicará, dentre eles, o seu presidente, que deverá ser ocupante de cargo efetivo superior ou de mesmo nível, classe e o padrão, ou ter nível de escolaridade igual ou superior ao do indiciado" e no artigo 171 enuncia que "Quando a infração estiver capitulada como crime, o processo disciplinar será remetido ao Ministério Público para instauração da ação penal", mantido traslado na repartição competente.

A matéria é regulada nos Estados e Municípios em legislação específica, observadas, entretanto, as normas constantes da lei federal acima referida. No RS, a Lei Complementar $n^{\mathrm{o}}$ 10.098/94, reiterando os termos da Lei $\mathrm{n}^{\mathrm{O}}$ 1.751. de 22 de fevereiro de 1952 do Estado do RS (Estatuto do Funcionário Público), dispõe sobre as sindicâncias preliminares, sobre o inquérito disciplinar e sobre o processo administrativo disciplinar propriamente dito, declarando, no art. 218, que se a autoridade processante imputar ao servidor a prática de crime cometido na esfera administrativa, ela determinará, além da instauração do processo administrativo disciplinar, providências para a instauração de inquérito policial, não havendo impedimento algum, ressalvamos nós, a que o Ministério Público desde logo dê início à ação e ao processo se visualizar nos autos as indispensáveis provas sobre autoria e materialidade da infração.

Então, se a autoridade reconheçer, em sindicância ou processo administrativo com base nela instaurado, a existência de prova que sugira infração penal, cumprirá mencionar, fundamentadamente, esse aspecto, em seu relatório final e assim propor ao superior hierárquico a remessa de cópia dos autos ao Ministério Público da Comarca ou à Procuradoria-Geral, quando houver mais de um representante da Instituição com atribuições idênticas, para a formação da opinio delicti capaz de redundar no início da persecução penal mediante denúncia.

A mesma conduta do servidor público pode caracaterizar ainda possibilidade de perda do cargo e, quando houver prejuízo ao erário, ação civil por improbidade administrativa. 


\section{(v) Investigação por órgãos integrantes dos sistemas tributário e nacional}

Na esfera admistrativa, também o Banco Central, a Comissão de Valores Mobiliários, o COAF (Conselho de Controle das Atividades Financeiras) e a Receita Federal detém atribuições legislativas para promoverem atos investigatórios por atividades definidas como infrações contra o sistema tributário e o sistema financeiro (Leis 8137, 7492 e 9613, respectivamente).

Com efeito, os artigos $2^{\circ}$, $\S \S 6^{\circ}$ e $9^{9}$ da Lei Complementar $\mathrm{n}^{\mathrm{o}}$ 105/00, que assegura o sigilo nas operações de instituições financeiras, declaram, respectivamente, que "O Banco Central do Brasil, a Comissão de Valores Mobiliários e os demais órgãos de fiscalização, nas áreas de suas atribuições, deverão fornecer ao Conselho de Controle de Atividades Financeiras - COAF, órgão de que trata o art. 14 da Lei $\mathrm{n}^{\mathrm{0}}$ 9.613, de 3 de março de 1998, as informações cadastrais e de movimento de valores relativos às operações previstas no inciso I do art. 11 da referida Lei" e que, ao verificarem a ocorrência ou indícios de prática de crime de ação pública, disso darão ciência “... ao Ministério Público, juntando à comunicação os documentos necessários à apuração ou comprovação dos fatos".

Os crimes a que se reporta o artigo 9ำ são aqueles apontados nos incisos do parágrafo $4^{\circ}$ do artigo $1^{\mathrm{O}}$ da mesma Lei Complementar $\mathrm{n}^{\mathrm{O}}$ 105, que ensejam declaração de quebra do sigilo fiscal, quais sejam, os de "I - de terrorismo; II - de tráfico ilícito de substâncias entorpecentes ou drogas afins; III - de contrabando ou tráfico de armas, munições ou material destinado a sua produção; IV - de extorsão mediante sequestro; $\mathrm{V}$ - contra o sistema financeiro nacional; VI - contra a Administração Pública; VII - contra a ordem tributária e a previdência social; VIII - lavagem de dinheiro ou ocultação de bens, direitos e valores; IX - praticado por organização criminosa", muitos dos quais aparecem descritos e qualificados no artigo $1^{\circ}$, inciso I a VIII da Lei 9.613, de 3 de março de 1998 também como crimes antecedentes ao crime de lavagem de dinheiro.

Essas condutas definidas como lavagem de dinheiro e que são voltadas à transformação do dinheiro sujo em ativos lícitos mediante investimentos nos distintos setores da economia, antigas e só agora merecedoras de maior punição, integram o centro das preocupações e das atribuições do novel órgão de controle e repressão denominado COAF - Conselho de Controle de Atividades Financeiras - vinculado ao Ministério da Fazenda.

Conforme consta de Cartilha sobre Lavagem de Dinheiro expedida pelo Ministério da Fazenda, a função primordial do COAF é "promover o esforço conjunto por parte dos vários órgãos governamentais do Brasil que cuidam da implementação de políticas nacionais voladas para o combate à lavagem de dinheiro, evitando que setores da economia continuem sendo utilizados nessas operações ilicitas".

Enfim, é do COAF, como órgão de inteligência do Ministério da Fazenda, a incumbência de investigar e de remeter às autoridades competentes com vistas aos procedimentos cabíveis os documentos recolhidos contendo notícia de crime em tese de lavagem de dinheiro, conforme consta do artigo 15 da Lei 9.613/98, in verbis: "O COAF comunicará às autoridades competentes para a instauração dos procedimentos cabíveis, quando concluir pela existência de crimes previstos nesta lei, de fundados indícios de sua prática, ou de qualquer outro ilícito".

Por causa da recente a tipificação penal promovida via Código Penal (arts. 359-A a 359-H) e Leis Federais no 4.729 , de 14 de julho de 1995 e no 8.137 , de 27 de dezembro de 1990, os órgãos de fiscalização financeira e de arrecadação tributária federais e estaduais detém a ínsita atribuição de conferir operações de crédito, despesas, prestações de contas, lançamentos contábeis ou documentos relacionados às atividades financeiras na área do serviço público e fiscais envolvendo pessoas pessoas físicas e jurídicas do país.

O Supremo Tribunal Federal, por exemplo, reconheceu que a Receita Federal tem poderes para consultar livros contábeis e notas fiscais da empresa que as emitiu em diligência destinada a apurar a emissão de "notas frias", incumbindo ao juiz do caso, como é óbvio, "formar a sua convicção sobre se a hipótese comporta ou não conluio entre os titulares das empresas contratante e contratada, em detrimento do erário" ${ }^{40}$.

Todas essas situações possibilitam-nos ver que as atividades investigatórias não são exclusivas e sim compartilhadas entre a polícia e outras autoridades do Poder Executivo, do Poder Judiciário e do próprio Ministério Público.

Elas concorrem com a polícia judiciária da União e dos Estados na relevante missão de reunir provas de prática de infração penal para a ainstrumentalização da ação penal.

\section{(vi) Investigação militar}

Os inquéritos policiais-militares constituem os instrumentos de que se valem as autoridades policiaismilitares para a investigação dos crimes da competência da justiça militar ${ }^{41}$.

De acordo com o Dec.-Lei 1.002/69, a polícia judiciária é exercida pelos Ministros da Marinha, 
Exército e Aeronáutica; pelo chefe do Estado-Maior das Forças Armadas; Comandantes de Região Militar; pelo Chefe do Estado-Maior e Secretário-Geral da Marinha, pelos Comandantes de Regiões Militares; Distrito Naval e Zona Aérea, pelo Secretário do Ministério do Exército e Chefe de Gabinete do Ministério da Aeronáutica; pelos Diretores e Chefes de Órgãos, Repartições ou Estabelecimentos ou Serviços previstos nas leis de organização básica da Marinha, do Exército e da Aeronáutica e pelos Comandantes das Forças, Unidades ou Navios.

Esses inquéritos possuem natureza jurídica e finalidade idênticas às do inquérito policial elaborado pela polícia civil, já examinadas.

Obviamente, que após as conclusões, os autos respectivos deverão ser enviados ao conhecimento do MP para eventuais providências na seara penal, administrativa ou civil.

\section{(vii) Investigação ambiental - A Lei no $\mathbf{4 . 7 7 1 / 6 5}$}

A Lei 4.771/65 (Código Florestal) que permanece em vigor, dispõe no artigo 33, que "São autoridades competentes para instaurar, presidir e proceder a inquéritos policiais, lavrar autos de prisão em flagrante e intentar a ação penal, nos casos de crimes ou contravenções, previstos nesta Lei, ou em outras leis e que tenham por objeto florestas e demais formas de vegetação, instrumentos de trabalho, documentos e produtos procedentes das mesmas" as "a) indicadas no Código de Processo Penal" e "b) os funcionários da repartição florestal e de autarquias, com atribuições correlatas, designados para a atividade de fiscalização".

Nos exatos termos desse Código, os funcionários da repartição florestal teriam atribuições concorrentes com as autoridades policiais para preparar os inquéritos e lavrar os autos de prisão em flagrante por infrações ambientais.

Impõe-se observar, contudo e primeiramente, que as condutas definidas no Código Florestal como contravenções (artigo 26, letras "a" a "q") foram definidas como crimes e deslocadas para o ámbito da Lei 9.605/98 (art. 38 e seguintes).

A investigação sobre a existência e a autoria dessas infrações se desenvolverá, portanto, a cargo das autoridades policiais e não dos servidores da repartição florestal, haja vista as novas disposições constitucionais já examinadas.

A reserva atribuições assegurada constitucionalmente à polícia judiciária não impede, como é óbvio, que os funcionários florestais fiscalizem e autuem os infratores da legislação ambiental, visando a aplicação das multas administrativas pertinentes, e, ato contínuo, remetam cópias da autuação à polícia judiciária para que o fato seja investigado mediante inquérito, desde que encontre definição típica como crime contra a flora.

Essa atividade pode ser conveniada com instituições estatais que atuem na área preventiva ou repressiva. No Estado do RS a Brigada Militar possui setor de policiamento ostensivo (PATRAM) voltado à defesa do meio-ambiente.

Embora não tenha atribuições para elaborar inquéritos, a Brigada Miliar poderá nessa atividade fiscalizar atividades ambientais, deter infratores ao ambiente e apresentá-los à autoridade civil, para a formalização de flagrantes e a elaboração de inquérito policial.

\section{REFERÊNCIAS}

ABRÃO, Guilherme Rodrigues. As Comissões Parlamentares de Inquérito e as garantias constitucionais frente ao Estado democrático e constitucional de direito. Porto Alegre: EDIPUCRS, 2008.

BITENCOURT, Cezar Roberto. A inconstitucionalidade da resolução $\mathrm{n}^{\mathrm{o}} 13$ do Conselho Nacional do Ministério Público. Boletim do IBCCrim, n. 170, jan. 2008.

DOTTI, René Ariel. O Ministério Público e a Polícia Judiciária - relações formais e desencontros materiais. In: $M P$, Direito e Sociedade. Fabris Editor e Escola Superior do MP do RS.

FELDENS, Luciano; SCHMIDT, Andrei Zenkner. Investigação criminal e ação penal. Porto Alegre: Verbo Jurídico, 2005.

GASPARINI, Diogenes. Direito administrativo. 9. ed. São Paulo: Saraiva, 2004

GIACOMOLLI, Nereu José. Juizados Especiais Criminais: Lei 9.099/95. Porto Alegre: Livraria do Advogado, 2002.

GRINOVER, Ada Pellegrini. Investigações pelo Ministério Público. Boletim do IBCCrim, São Paulo, v. 12, n. 145, p. 4.

KLEIN, Odacir. Comissões Parlamentares de Inquérito - a sociedade e o cidadão. Porto Alegre: Fabris, 1999.

MELLO FILHO, José Celso. Investigação Parlamentar Estadual: as Comissões Especiais de Inquérito. In: Justitia, v. 121.

MIRANDA, Pontes. In: KLEIN, Odacir. Comissões Parlamentares de Inquérito - a sociedade e o cidadão. Porto Alegre: Fabris, 1999.

ROSAS, Roberto. Direito sumular. 13. ed. São Paulo: Malheiros, 2006.

SALIM, Alexandre Aranalde. O Inquérito Policial. In: MARTINS, Charles Emil Machado (Org.). Teoria e prática dos procedimentos criminais e ações autônomas de impugnação. Porto Alegre: Livraria do Advogado, 2009.

SILVA, José Afonso. Controle externo da atividade policial como uma das funções institucionais do MP. Revista ADPESP, ano 17, n. 22 , dez. 98 . 


\section{NOTAS}

1 Ex-Promotor e Procurador-de Justiça. Desembargador aponsentado do Rio Grande do Sul. Professor de Processo Penal na PUCRS.

2 SALIM, Alexandre Aranalde, O Inquérito Policial, in MARTINS, Charles Emil Machado (org.), Teoria e prática dos procedimentos criminais e ações autônomas de impugnação, Livraria do Advogado, 2009, p. 32.

3 SALIM, Alexandre Aranalde, O Inquérito Policial, in MARTINS, Charles Emil Machado (org.), Teoria e prática dos procedimentos criminais e ações autônomas de impugnação, Livraria do Advogado, (Charles Emil Machado Martins, Org.), 2009, p. 32.

${ }^{4}$ DOTTI, René Ariel. O Ministério Público e a Polícia Judiciária Relações Formais e Desencontros Materiais, in MP., Direito e Sociedade, publicação da Associação do Ministério Público do RS, Fabris Editor e Escola Superior do MP do RS, p. 123.

5 Pet-QO 3825/MT - MATO GROSSO, Relator(a): Min. SEPÚLVEDA PERTENCE, Relator(a) p/ Acórdão: Min. GILMAR MENDES, Julgamento: 10/10/2007, Tribunal Pleno.

6 "Art. 61. Consideram-se infrações penais de menor potencial ofensivo, para os efeitos desta Lei, as contravenções penais e os crimes a que a lei comine pena máxima não superior a 2 (dois) anos, cumulada ou não com multa." (Redação dada pela Lei no 11.313, de 2006). A doutrina e a jurisprudência vem entendendo que, no concurso material (art. 69 do CP), deverão ser somadas as penas máximas cominadas em abstrato às infrações em concurso, para poder-se aferir a competência do JEC. Se as penas somadas ultrapassarem a dois anos, o processo deverá ser instaurado perante o Juízo Comum. Tratando-se de concurso formal ou de crime continuado, esse controle será realizado mediante a máxima incidência das majorantes previstas nos arts. 70 e 71 do CP sobre o máximo de pena privativa de liberdade cominado em abstrato à infração mais grave, se diversas, ou à pena privativa de liberdade cominada para qualquer delas, se iguais. Da mesma forma, se o resultado final ultrapassar ao limite legal (2 anos), o caso será apreciado pelo Juizado Comum e não pelo JEC. No crime tentado o controle da cometência do JEC ocorerá mediante a redução da pena máxima cominada em abstrato ao fato o quantum correspondente ao mínimo pervisto no art. 14 do CP. Se o resultado for interior a dois anos, a competência para o processo e o julgamento será do JEC. Se for superior, do Juizado Comum.

GIACOMOLLI. Nereu José. Juizados Especiais Criminais: Lei 9.099/95. Porto Alegre: Livraria do Advogado, 2002, p. 88.

8 "A Brigada Militar também possui competência para a lavratura do Termo Circunstanciado, especialmente tendo o autor do fato assinado o termo de comparecimento ao Juizado Especial Criminal. Havendo prova do fato, deve ser mantida a sentença condenatória. NEGARAM PROVIMENTO." (Recurso Crime n⿳o 71000863100, Turma Recursal Criminal, Turmas Recursais, Relator: Alberto Delgado Neto, Julgado em 04/12/2006).

9 HC 7199/PR, 6- T., rel. Min. Vicente Leal, j. em $1^{\text {o }}$ de julho de 1998, in DJ 28/09/1998 p. 115.

${ }^{10}$ ADI 3.441, Rel. Min. Carlos Britto, julgamento em 05/10/06, DJ de 09/03/07.

${ }^{11}$ MELLO FILHO, José Celso, Investigação Parlamentar Estadual: As Comissões Especiais de Inquérito, in Justitia, v. 121, p. 155 e seguintes.

12 "Escusaria advertir que, se se perde CPI na investigação de fatos outros que não o determinado como seu objeto formal, configuram-se-lhe desvio e esvaziamento de finalidade, os quais inutilizam o trabalho desenvolvido, afrontando a destinação constitucional, que é a de servir de instrumento poderoso do Parlamento no exercício da alta função política de fiscalização. Nenhum parlamentar pode, sem descumprimento de dever de ofício, consentir no desvirtuamento do propósito que haja norteado a criação de CPI e na consequente ineficácia de suas atividades" (MS25.885-MC, Rel. Min. Cezar Peluso, decisão monocrática, julgamento em 16/03/06, DJ de 24/03/06.

13 MIRANDA, Pontes, in KLEIN, Odacir, Comissões Parlamentares de Inquérito - A sociedade e o cidadão. Porto Alegre, Fabris, 1999, p. 34.

${ }^{14}$ (HC 86.431-MC, Rel.Min. Carlos Britto, decisão monocrática, julgamento em 08/08/05, DJ de 19/08/05.

${ }^{15}$ FELDENS, Luciano e Andrei Zenkner Schmidt, Investigação Criminal e Ação Penal, Porto Alegre, Verbo Jurídico, 2005, p. 91.

16 "As Comissões Parlamentares de Inquérito e as Garantias Constitucionais frente ao Estado Democrático e Constitucional de Direito", PUCRS, 2008.

17 Art. 59. O processo legislativo compreende a elaboração de: I- emendas à Constituição; II - leis complementares; III - leis ordinárias; IV - leis delegadas; V - medidas provisórias; VI - decretos legislativos; VII resoluções.
18 KLEIN, Odacir, Comissões Parlamentares de Inquérito - A sociedade e o Cidadão - Porto Alegre, Fabris, 1999, p. 23.

${ }^{19}$ HC 80.152-MC, Rel Min. Nelson Jobim.

${ }^{20}$ HC 88.189-MC, Rel. Min. Celso de Mello, decisão monocrática, julgamento em 07/03/06, DJ de 14/03/06.

${ }^{21}$ MELLO FILHO, José Celso, Investigação Parlamentar Estadual: As Comissões Especiais de Inquérito, in Justitia, v. 121, p. 155 e seguintes.

22 "A jurisprudência desta Corte é firme no sentido de admitir a quebra de sigilos fiscal, bancário e telefônico efetivada por comissões parlamentares de inquérito, desde que os requerimentos sejam fundamentados, apresentando fatos concretos que justifiquem causa provável para a efetivação da medida excepcional: ... (MS n. 25.668-MC, DJ de 24/11/05). No mesmo sentido o MS n. 25.631-MC, Relator o Ministro Sepúlveda Pertence, DJ de 10/11/05." (MS 26.909, Rel. Min.Eros Grau, decisão monocrática, julgamento em 04/10/07, DJ de 11/10/07).

${ }^{23}$ Leis 9.296, de 24.7.1996 (lei da escuta telefônica) e Lei 6.538, de 22/06/1978 (lei dos serviços postais).

${ }^{24}$ ROSAS, Roberto, Direito sumular, São Paulo, Malheiros, 13. ed., 2006, p. 178.

25“"§ $2^{\mathrm{O}}-$ Quando, no curso de investigação, houver indício de prática de infração penal por parte de membro do Ministério Público, a autoridade policial estadual remeterá imediatamente os respectivos autos ao Procurador-Geral de Justiça, a fim de que este prossiga na investigação".

${ }^{26}$ A colenda $2^{\mathrm{a}}$ Turma do STF, em HC de que foi relator o min. Celso de Melo, afirmou que o Ministério Público dispõe de competência para promover, por autoridade própria, investigações de natureza penal, desde que respeitados os direitos e garantias que assistem a qualquer indiciado ou a qualquer pessoa sob investigação do Estado, observadas, sempre, pelos agentes de tal órgão, as prerrogativas profissionais de que se acham investidos os advogados, sem prejuízo da possibilidade - sempre presente no Estado Democrático de Direito - do permanente controle jurisdicional dos atos praticados pelos promotores de justiça e procuradores da república. Com base nesse entendimento, a Turma indeferiu habeas corpus em que se alegava a nulidade de ação penal promovida com fulcro em procedimento investigatório instaurado exclusivamente pelo Ministério Público e que culminara na condenação do paciente, delegado de polícia, pela prática do crime de tortura (HC 89837/DF, rel. Min. Celso de Mello, 20/10/2009. (HC 89837) - in Boletim n. 564.

${ }^{27}$ FELDENS, Luciano e Andrei Zenkner Schmidt, Investigação Criminal e ação penal, Porto Alegre, Verbo Jurídico, 2005, p. 83.

${ }^{28}$ RHC nº 10111/DF, rel. Min. Edson Vidigal, julgado em 06/09/2001; HC 41615, MG, min. Arnaldo Esteves Lima, 5 $5^{\mathbf{a}}$ Turma, julgado em 06/04/2006; RESp 761.938/SP, rel. Min. Gilson Dipp, 5를., julgado em 04/04/2006, HC 38495/SC, rel. Min. Hélio Quaglia Barbosa, 6a T. e HC 35.654/RO, rel. Min. Carvalhido, $6^{-}$T., julgado em 07/03/2006.

${ }^{29}$ A Constituição Federal dotou o Ministério Público do poder de requisitar diligências investigatórias e a instauração de inquérito policial $(\mathrm{CF}$, art. 129 , VIII). A norma constitucional não contemplou a possibilidade do parquet realizar e presidir inquérito policial. Não cabe, portanto, aos seus membros inquirir diretamente pessoas suspeitas de autoria de crime. Mas requisitar diligência nesse sentido à autoridade policial. Precedentes. O recorrente é delegado de polícia e, portanto, autoridade administrativa. Seus atos estão sujeitos aos órgãos hierárquicos próprios da Corporação, Chefia de Polícia, Corregedoria. Recurso conhecido e provido (RHC 81326/DF; Relator: Min. NELSON JOBIM; Julgamento: 06/05/2003; Órgão Julgador: Segunda Turma; DJ 01/08/2003 PP-00142)

30 Até o presente momento haviam votado três ministros pela constitucionalidade da Resolução e outros dois pela inconstitucionalidade.

31 BITENCOURT, Cezar Roberto, A inconstitucionalidade da resolução no 13 do Conselho Nacional do Ministério Público, IBCCrim, n. 170, p. 11, jan. 2008.

32 É o caso do inquérito civil público (Lei 7.347/85), para defesa do meio ambiente ou do patrimônio público.

Ainda, o inquérito previsto no ECA (Lei 8.069/90).

"Abuso sexual contra menor. Lgitimidade do Ministério Público para instaurar sindicância. estatuto da criança e do adolescente (ECA). O Ministério Público tem legitimidade para instaurar sindicância para a apuração de crimes previstos no Estatuto da Criança e do Adolescente (art. 201, inciso VII, da Lei 8.069/90). Além da competência que lhe atribui o ECA, é pacífico o entendimento desta Corte de que o Ministério Público não necessita de inquérito policial para instaurar ação penal. Caso que não se confunde com o RHC 81.326 que tratava de falta de legitimidade do Parquet para presidir ou desenvolver diligências pertinentes ao inquérito policial. A questão relativa à infância e à juventude é regulada por lei especial que tem previsão específica (Lei 
8.069/90). Habeas corpus indeferido" (HC N. 82.865-GO, rel. Min. Nelson Jobim).

Ainda no Estatuto do Idoso: Lei 10.741/00 - art. 74

33 EMENTA: HABEAS CORPUS. INVESTIGAÇÃO CRIMINAL. MINISTÉRIO PÚBLICO. Como titular da ação penal, nada impede o Ministério Público, recebendo diretamente notícia-crime, de proceder a diligências para os esclarecimentos que julgar pertinentes à formulação da sua opinião, não estando, assim, obrigado, para tal, a requisitar inquérito policial. Fatos noticiados que diriam com lavagem de dinheiro e estelionato, envolvendo entidade ligada a seguro e previdência privada. No exercício de suas funções investigatórias, que não se confundem com inquérito policial, este, sim, atribuição específica da autoridade policial, pode o Ministério Público expedir notificações, com advertência de possível condução. Participação de advogado negada em certa audiência por falta de procuração outorgada pelo inquirido. Ordem denegada. (Habeas Corpus 70009567843, Sétima Câmara Criminal, Tribunal de Justiça do RS, Relator: Marcelo Bandeira Pereira, julgado em 07/10/2004).

${ }^{34}$ Adin 2797/2 - voto proferido pelo Min. Celso de Mello.

35 SILVA, José Afonso da, Controle Externo da Atividade Policial como uma das Funções Institucionais do MP. Revista ADPESP, ano 17, n. 22, p. 19 , dez. 1998.

${ }^{36}$ GRINOVER, Ada Pellegrini, Investigações pelo Ministério Público, Boletim do IBCCrim, São Paulo, v. 12, n. 145, p. 4.

37 GASPARINI, Diogenes. Direito administrativo. 9. ed. São Paulo: Saraiva, 2004, p. 863.

38 Apelação Cível no 70002317139, Terceira Câmara Cível, Tribunal de Justiça do RS, Relator: Augusto Otávio Stern, julgado em 31/05/2001 “e 2. Para o exercício desses dois princípios constitucionais,basilares do processo administrativo, o estatuto dos servidores públicos federais assegura aos acusados o direito de acompanhar o processo disciplinar, pessoalmente ou por intermédio de procurador. 3. Tendo a própria autoridade coatora reconhecido que o Impetrante só fora citado para acompanhar o processo, depois de encerrada a instrução, quando deveria ser indiciado e, posteriormente, apresentar defesa escrita, o processo é nulo, a partir da iniciação do inquérito, com todos os atos subsequentes" (MS 10788/DF, 3ª Secção, rel. Paulo Medina, j. em 14/03/2007, in DJ 02/04/2007 p. 226), dentre outros julgados.

39 GASPARINI, Diogenes. Direito administrativo. 9. ed. São Paulo: Saraiva, 2004, p. 850-851.

${ }^{40}$ RHC 74807 / MT, rel. Min. Maurício Correa, j. em 22/04/97, in DJ 20/06/1997 PP-28507.

41 "A jurisprudência desta Corte orienta-se no sentido de que, em se tratando de punição disciplinar por transgressão militar, só se pode admitir a análise da legalidade do ato, via habeas corpus, quando se encontrar em jogo a liberdade de ir e vir do cidadão, que é a hipótese dos autos. Verificada a presença de indícios de infração penal, a instauração de sindicância configura ofensa ao devido processo legal e, em conseqüência, está eivada de vício, pois a via adequada para tal apuração é o inquérito policial militar. Sobressai ilegalidade flagrante no procedimento atacado, no tocante à deficiência da defesa do paciente por ofensa ao devido processo legal.Deve ser cassado o acórdão recorrido

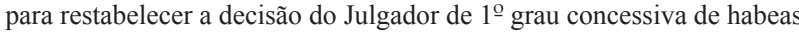
corpus ao recorrente. Recurso provido, nos termos do voto do Relator" (RHC 17422/RN, rel. Min. Gilson Dipp, julgado em 29/09/2006, in DJ 23/10/2006, p. 325). 